\title{
Peran Guru dalam Pendidikan Karakter Selama Pandemi Covid-19 di SMP Negeri 1 Sumbang
}

\author{
The Role of Teachers in Character Education \\ During the Covid-19 Pandemic at SMP Negeri 1 Sumbang
}

Ari Wijayanti ${ }^{1}$, Sriyanto ${ }^{2}$

${ }^{1,2}$ Magister PIPS, Universitas Muhammadiyah Purwokerto

\begin{tabular}{l}
\hline \hline ARTICLE INFO \\
\hline Article history: \\
DOI: \\
10.30595/pssh.v1i.67 \\
Submitted: \\
April 12, 2021 \\
Accepted: \\
June 10, 2021 \\
Published: \\
June 14, 2021
\end{tabular}

Keywords:

Role of teachers, character education, pandemic covid-19

\begin{abstract}
A teacher carries out a very noble task in addition to educating and providing transparency for students, namely making his students have good morals and noble character. Thus, a teacher must be able to make his students into noble human beings. Teachers play an important role even very important in terms of educating and providing transparency for their students. During the pandemic as it is today it is a challenge for teachers in Indonesia to instill character education. Character education is an effort to realize a generation of intelligent and good national (smart and good citizenship) or have a noble and Indonesian personality. The success of character education hints at learning not necessarily seen from the perspective of the cognitive realm alone but rather how the balance of the cognitive, affective, and psychomotor realms that estuary is to realize the whole human being. The condition of the Covid19 pandemic is currently a challenge for the world of education, especially formal education in the efforts to education the character of the nation. Dominant learning is not done face-to-face, so it becomes a teacher's challenge in the process of character education. On the other hand, it will provide opportunities as learners in actualizing the values of character in the community in an effort to participate in the prevention and prevention of Covid-19. This research is descriptive qualitative with literature studies that seek to provide solutions to how character education is conducted while learning is still taking place by online methods in junior high school.
\end{abstract}

This work is licensed under a Creative Commons Attribution 4.0 International License.

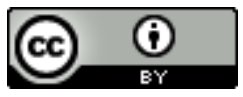

Corresponding Author:

Ari Wijayanti

Magister PIPS, Universitas Muhammadiyah Purwokerto

Jalan KH. Ahmad Dahlan, PO BOX 202 Purwokerto, 53182, Kembaran, Banyumas, Jawa Tengah, Indonesia.

Email: arijolik@gmail.com

\section{PENDAHULUAN}

Karakter adalah cara berpikir dan berperilaku yang menjadi ciri khas tiap individu untuk hidup dan bekerjasama, baik dalam lingkup keluarga, masyarakat, bangsa dan negara. Individu yang berkarakter baik adalah individu yang bisa membuat keputusan dan siap mempertanggung jawabkan tiap akibat dari keputusan yang ia buat. Pembentukan karakter merupakan salah satu tujuan pendidikan nasional. Tujuan pendidikan nasional diantaranya adalah mengembangkan potensi peserta didik untuk memiliki kecerdasan, kepribadian, dan akhlak mulia [1]. Karakter akan membentuk motivasi, yang dibentuk dengan metode dan proses yang bermartabat. Selain penampilan lahiriah, karakter juga mengungkapkan secara implisit hal-hal yang tersembunyi. Karakter yang baik mencakup pengertian, kepedulian, dan tindakan berdasarkan nilai etika, serta meliputi aspek kognitif, emosional, dan perilaku dari kehidupan moral.

"Pendidikan Karakter merupakan bentuk kegiatan manusia yang di dalamnya terdapat suatu tindakan yang mendidik diperuntukkan bagi generasi selanjutnya, dengan membentuk penyempurnaan diri 
individu secara terus menerus dan melatih kemampuan diri demi menuju ke arah hidup yang lebih baik"[2]. Pendidikan karakter adalah suatu metode pendidikan yang dilakukan oleh tenaga pendidik untuk mempengaruhi karakter murid. Dalam hal ini terlihat bahwa guru bukan hanya mengajarkan materi pelajaran tetapi juga mampu menjadi seorang teladan (Elkind). Secara umum fungsi pendidikan ini adalah untuk membentuk karakter seorang peserta didik sehingga menjadi pribadi yang bermoral, berakhlak mulia, bertoleran, tangguh, dan berperilaku baik.

Sementara pandemi Covid-19 yang melanda dunia pada awal tahun 2020, dengan cepat mengubah tatanan kehidupan masyarakat, termasuk Indonesia. Dunia pendidikan "dipaksa" mengganti pembelajaran tatap muka dengan pembelajaran online/daring. Para peserta didik melanjutkan pendidikannya melalui pembelajaran online dan video call dengan guru mereka, Model tersebut saat ini merupakan alternatif terbaik karena menjaga sekolah tetap terbuka maka dapat menimbulkan risiko keselamatan bagi peserta didik. Keadaan tidak kondusif yang berlangsung lama ini, salah satunya disebabkan karena sebagian masyarakat banyak yang tidak mematuhi protocol kesehatan. Mereka sudah terlalu lelah berdiam diri di rumah sehingga mengacuhkan protocol kesehatan yang dicanangkan oleh pemerintah dan hasilnya kurang efektif berdasarkan data yang terkena virus terus meningkat.

Bagi sebagian besar peserta didik sekolah online sangat membingungkan untuk menyesuaikan diri karena mereka belum dipersiapkan melalui simulasi atau praktik sebelumnya. Peserta didik melaporkan bahwa program belajar di rumah lebih membuat stres daripada di ruang kelas. Kelas online membuat peserta didik terjebak sendirian hanya dengan tugas. Beberapa orang tua juga banyak yang mengeluh terkait pembelajaran daring yang membuat anak-anak mereka mengalami penurunan akhlak. Di lain sisi, guru juga mengalami kendala untuk dapat membentuk karakter yang ingin dicapai. Kendala yang tidak dapat dijangkau oleh teknologi, bahkan teknologi tidak dapat menyentuh salah satu inti dari pendidikan, yaitu pendidikan karakter. Disinilah peran guru mempunyai tanggung jawab yang besar dalam menanamkan dan mengembangkan pendidikan karakter.

Undang-undang Republik Indonesia nomor 20 tahun 2003 tentang system Pendidikan Nasional (UU Sisdiknas) merumuskan fungsi dan tujuan pendidikan nasional yang harus digunakan dalam pengembangan upaya pendidikan di Indonesia. Pasal 3 UU Sisdiknas menyebutkan, "Pendidikan nasional berfungsi mengembangkan dan membentuk watak serta peradaban bangsa yang bermartabat dalam rangka mencerdaskan kehidupan bangsa, bertujuan untuk berkembangnya potensi peserta didik agar menjadi manusia yang beriman dan bertakwa kepada Tuhan Yang Maha Esa, berakhlak mulia, sehat, berilmu, cakap, kreatif, mandiri,dan menjadi warga negara yang demokratis sertabertanggung jawab". Tujuan pendidikan nasional itu merupakan rumusan mengenai kualitas manusia Indonesia yang harus dikembangkan oleh setiap satuan pendidikan. Oleh karena itu, rumusan tujuan pendidikan nasional menjadi dasar dalam pengembangan pendidikan budaya dan karakter bangsa. Pada prinsipnya, pengembangan budaya dan karakter bangsa tidak dimasukkan sebagai pokok bahasan tetapi terintegrasi ke dalam mata pelajaran -mata pelajaran, pengembangan diri, dan budaya sekolah. Oleh karena itu, guru dan sekolah perlu mengintegrasikan nilai-nilai yang dikembangkan dalam pendidikan budaya dan karakter bangsa ke dalam Kurikulum, Silabus dan Rencana Program Pembelajaran (RPP) yang sudah ada.

Prinsip pembelajaran yang digunakan dalam pengembangan pendidikan budaya dan karakter bangsa mengusahakan agar peserta didik mengenal dan menerima nilai-nilai budaya dan karakter bangsa sebagai milik mereka dan bertanggung jawab atas keputusan yang diambilnya melalui tahapan mengenal pilihan, menilai pilihan, menentukan pendirian, dan selanjutnya menjadikan suatu nilai sesuai dengan keyakinan diri. Dengan prinsip ini, peserta didik belajar melalui proses berpikir, bersikap, dan berbuat. Ketiga proses ini dimaksudkan untuk mengembangkan kemampuan peserta didik dalam melakukan kegiatan sosial dan mendorong peserta didik untuk melihat diri sendiri sebagai makhluk sosial.

Nilai-nilai yang dikembangkan dalam pendidikan budaya dan karakter bangsa diidentifikasikan dari sumbersumber inti. Sumber yang dimaksud adalah Agama, Pancasila, budaya, dan tujuan pendidikan nasional. Dengan bersumber dari nilai-nilai luhur, karakter bisa dibentuk sesuai dengan tujuan pendidikan. Sejalan dengan hal tersebut pemerintah memperbaharui kebijakan pendidikan yang tujuan utamanya adalah untuk mengimplementasikan Nawacita dalam sistem pendidikan nasional. Nilai-nilai utama Penguatan Pendidikan Karakter ( PPK ) adalah religius, nasionalis, mandiri, gotong royong, integritas. Nilai-nilai ini ingin ditanamkan dan dipraktikkan melalui sistem pendidikan nasional agar diketahui, dipahami, dan diterapkan di seluruh sendi kehidupan di sekolah dan di masyarakat. PPK lahir karena kesadaran akan tantangan ke depan yang semakin kompleks dan tidak pasti, namun sekaligus melihat ada banyak harapan bagi masa depan bangsa. Hal ini menuntut lembaga pendidikan untuk mempersiapkan peserta didik secara keilmuan dan kepribadian, berupa individu-individu yang kokoh dalam nilainilai moral, spiritual dan keilmuan. Memahami latar belakang, urgensi, dan konsep dasar PPK menjadi sangat penting bagi Kepala Sekolah dan para guru di SMP Negeri 1 Sumbang agar dapat menerapkannya sesuai dengan konteks pendidikan di daerah Sumbang. Karena pada umumnya sekolah cenderung mengutamakan tercapainya bidang akademik, sedangkan bidang non akademik berupa tingginya nilai-nilai moral, karakter dan psikologis siswa sedikit dikesampingkan. Padahal itu jauh lebih penting dalam pembentukan martabat manusia.

Dari penjelasan tersebut penulis menetapkan tujuan diantaranya adalah : 
- Mengetahui seberapa besar peran guru dalam pendidikan karakter di masa pandemic ini pada siswa-siswi di SMP Negeri 1 Sumbang.

- Mengetahui Indikator karakter apa saja yang bisa dilaksanakan di SMP N 1 Sumbang dengan baik.

\section{METODE PENELITIAN}

Penelitian ini merupakan penelitian yang menggunakan metode penelitian kualitatif. [3] Penelitian kualitatif adalah metode penelitian naturalistik karena penelitiannya dilakukan pada kondisi yang alamiah (natural setting) atau pada obyek yang alamiah. Obyek yang alamiah adalah obyek yang berkembang apa adanya tidak dimanipulasi oleh peneliti dan kehadiran peneliti tidak merubah dinamika pada obyek tersebut". Dan metode yang dipilih adalah metode studi kasus. Metode studi kasus merupakan salah satu jenis penelitian kualitatif, dimana peneliti melakukan eksplorasi secara mendalam terhadap program, kejadian, proses, aktivitas, terhadap satu atau lebih orang.[4]

Dalam penelitian ini, penulis mengungkap peran guru terhadap pendidikan karakter di SMP Negeri 1 Sumbang dalam pembelajaran secara daring ( online ) seperti melaksanakan perancanaan pembelajaran, pengelola pembelajaran, pengarah pembelajaran, evaluator dan konselor. Pembelajaran yang dilaksanakan di SMP Negeri 1 Sumbang pada masa pandemi Covid-19 yaitu diantaranya dengan menggunakan website resmi sekolah (smpnegeri1sumbang.sch.id), Aplikasi Right Choice, google class room serta whatsapp. Dari pembelajaran melalui beberapa aplikasi tersebut menggambarkan proses pembelajaran dalam menginternalisasikan penanaman pendidikan karakter kepada siswa, serta menggambarkan faktor-faktor yang menjadi penghambat dalam kegiatan tersebut.

\section{HASIL DAN PEMBAHASAN}

\section{a) Hakikat Peran Guru}

Peran memiliki makna yaitu seperangkat tingkat yang diharapkan[6]. Sementara itu guru merupakan suatu profesi, yang berarti suatu jabatan yang memerlukan keahlian khusus sebagai guru dan tidak dapat dilakukan oleh sembarang orang di luar bidang pendidikan. Untuk seorang guru perlu mengetahui dan dapat menerapkan beberapa prinsip mengajar agar dapat melaksanakan tugasnya secara profesional. Diantaranya,

(1) Guru harus dapat membangkitkan perhatian peserta didik pada materi pelajaran yang diberikan serta dapat menggunakan berbagai media dan sumber belajar yang bervariasi.

(2) Guru harus dapat membangkitkan minat peserta didik untuk aktif dalam berfikir serta mencari dan menemukan sendiri pengetahuan.

(3) Guru harus mengembangkan sikap peserta didik dalam membina hubungan sosial, baik dalam kelas maupun luar kelas.

(4) Guru harus menyelidiki dan mendalami perbedaan peserta secara individual agar dapat melayani peserta didik sesuai dengan perbedaannya tersebut.

\section{b) Peran Guru Terhadap Pendidikan Karakter}

Terdapat beberapa peran guru dalam pembelajaran yang dikemukakan oleh Moon [5], yaitu sebagai berikut.

1. Guru sebagai Perancang Pembelajaran (Designer Of Instruction)

Sesuai dengan program yang diajukan oleh pihak Departemen Pendidikan Nasional guru dituntut untuk berperan aktiif dalam merencanakan KBM (Kegiatan Belajar Mengajar) dengan memperhatikan berbagai komponen dalam sistem pembelajaran. Jadi, guru dengan waktu yang sedikit atau terbatas tersebut, guru dapat merancang dan mempersiapkan semua komponen agar berjalan dengan efektif dan efisien. Untuk itu guru harus memiliki pengetahuan yang cukup memadai tentang prinsip-prinsip belajar, sebagai landasan dari perencanaan.

2. Guru sebagai Pengelola Pembelajaran (Manager Of Instruction)

Tujuan umum pengelolaan kelas adalah menyediakan dan menggunakan fasilitas bagi bermacam-macam kegiatan belajar mengajar. Sedangkan tujuan khususnya adalah mengembangkan kemampuan siswa dalam menggunakan alatalat belajar, menyediakan kondisi-kondisi yang memungkinkan siswa bekerja dan belajar, serta membantu siswa untuk memperoleh hasil yang diharapakan. Selain itu guru juga berperan dalam membimbing pengalaman sehari-hari ke arah pengenalan tingkah laku dan kepribadiannya sendiri.

3. Guru sebagai pengarah pembelajaran

Disini hendaknya guru senantiasa berusaha menimbulkan, memelihara, dan meningkatkan motivasi peserta didik untuk belajar. Dalam hubungan ini, guru mempunyai fungsi sebagai motivator dalam keseluruhan kegiatan belajar mengajar. Pendekatan yang dipergunakan oleh guru dalam hal ini adalah pendekatan pribadi, dimana guru dapat mengenal dan memahami siswa secara lebih mendalam hingga dapat membantu dalam keseluruhan PBM, atau dengan kata lain, guru berfungsi sebgai pembimbing.

4. Guru sebagai Evaluator (Evaluator Of Student Learning)

Tujuan utama penilaian adalah untuk melihat tingkat keberhasilan, efektivitas, dan efisiensi dalam proses pembelajaran. Selain itu, untuk mengetahui kedudukan peserta dalam kelas atau kelompoknya. Dalam fungsinya 
sebagai penilai hasil belajar peserta didik, guru hendaknya secara terus menerus mengikuti hasil belajar yang telah dicapai peserta didik dari waktu ke waktu untuk memperoleh hasil yang optimal.

5. Guru sebagai Konselor

Sesuai dengan peran guru sebagai konselor adalah guru diharapkan akan dapat merespon segala masalah tingkah laku yang terjadi dalam proses pembelajaran. Serta pada akhirnya, guru akan memerlukan pengertian tentang dirinya sendiri, baik itu motivasi, harapan, prasangka, ataupun keinginannya. Hal ini memberikan pengaruh pada kemampuan guru dalam berhubungan dengan orang lain, terutama siswa.

\section{c) Pengelolaan kelas}

Secara umum tugas guru sebagai pengelola pembelajaran adalah menyediakan dan menggunakan fasilitas kelas yang kondusif bagi bermacammacam kegiatan belajar mengajar agar mencapai hasil yang baik. Lingkungan belajar yang kondusif adalah lingkungan yang bersifat menantang dan merangsang peserta untuk mau belajar, memberikan rasa aman dan kepuasan dalam mencapai tujuan. Sejalan dengan hal tersebut, maka guru harus memiliki keterampilan mengelola kelas. Keterampilan mengelola kelas adalah keterampilan guru untuk menciptakan dan memelihara kondisi belajar yang optimal dan keterampilan untuk mengembalikan kondisi belajar yang optimal, apabila terdapat gangguan dalam proses belajar, baik yang bersifat gangguan kecil dan sementara maupun gangguan yang berkelanjutan [7]. Tujuan keterampilan mengelola kelas tidak hanya penting bagi guru, tetapi penting juga bagi siswa. Selain itu untuk guru, keterampilan mengelola kelas dapat mengembangkan pengertian dan keterampilan dalam memelihara kelancaran penyajian dan langkah-langkah proses belajar yang efektif. Serta memiliki kesadaran terhadapkebutuhan siswa dan mengembangkan potensinya dalam memberikan pengarahan yang jelas kepada siswa, dan memberi respon secara efektif terhadap tingkah laku siswa yang menimbulkan gangguan kecil atau ringan, serta memahami dan menguasai seperangkat kemungkinan strategi yang dapat digunakan dalam mengatasi masalah penyimpangan perilaku siswa yang berlebihan atau terus menerus melawan di kelas.

Komponen keterampilan mengelola kelas yang harus dimiliki guru yakni:

1. Keterampilan penciptaan dan pemeliharaan kondisi belajar optimal yakni dengan menunjukan sikap tanggap. Guru memperlihatkan sikap positif terhadap setiap perilaku peserta didik yang muncul dan memberikan tanggapan atas perilaku tersebut, dengan maksud tidak menyudutkan kondisi peserta didik, perasaan tertekan dan memunculkan perilaku susulan yang kurang baik. Perhatian guru harus terbagi merata kepada setiap anak yang berada di dalam kelas.

2. Keterampilan penciptaan dan pemeliharaan kondisi belajar optimal, yakni dengan memodifikasi tingkah laku. Memodifikasi tingkah laku dimaksudkan menyesuaikan bentuk-bentuk tingkah laku ke dalam tuntutan kegiatan pembelajaran, sehingga tidak muncul prototype pada diri peserta didik tentang peniruan perilaku yang kurang baik. Serta menemukan dan memecahkan perilaku yang menimbulkan masalah. Guru harus dapat mendeteksi permasalahan yang mungkin muncul dan secara cepat mengambil langkah penyelesaian sebagai solusi terhadap masalah.

Berdasarkan hasil wawancara dengan guru-guru di SMP Negeri 1 Sumbang, bahwa dalam setiap perancangan, pengelolaan, dan pengarahan pembelajaran, serta sebagai evaluator dan konselor terhadap hasil belajar siswa, peran guru di dalam kelas online ini selalu menanamkan nilai-nilai utama PPK yaitu diantaranya; religius, nasionalis, mandiri, gotong royong dan integritas kepada siswa dalam setiap kegiatan belajar mengajar dalam jaringan (daring/online).

1. Peran Guru sebagai Perancang Pembelajaran (Designer of Instruction)

Dari hasil temuan yang telah dilakukan oleh peneliti melalui studi wawancara dan observasi, peran guru sebagai perancang pembelajaran telah menanamkan nilai-nilai karakter pada siswa dengan membuat sebuah rancangan pembelajaran untuk kegiatan pelaksanaan belajar mengajar di kelas online. Dalam hal ini peranan guru sebagai perancang pembelajaran salah satunya dalam membuat Rencana Pelaksanaan Pembelajaran (RPP) telah berusaha menanamkan nilai-nilai karakter alam diri siswa, hal tersebut terlihat dari isi penulisan RPP yang telah dibuat oleh guru. Dengan analisis yang dilakukan peneliti, bahwa dalam penulisan isi RPP dari standar kompetensi dan kompetensi dasar karakter yang muncul adalah rasa nasionalis yaitu peduli lingkungan dimana mereka tinggal, menghargai dimana siswa diharapkan dapat menghargai jasa para pahlawan yang implementasinya siswa dapat mengambil contoh sikap dan perilaku tokoh pahlawan di kehidupan sehari-hari sehingga penanaman karakter yang dilakukan guru kepada siswa bisa muncul karakter menghargai. Dalam tujuan pembelajaran muncul karakter pantang menyerah, dimana siswa mengetahui peristiwa perjuangan para pejuang yang dengan semangat mengusir para penjajah, secara jelas dengan demikian siswa dapat mengambil sikap pantang menyerah yang ditunjukan oleh para tokoh pejuangnya terdahulu.

Dari karakter yang muncul pada SK, KD, indikator dan tujuan pembelajaran, karakter tersebut sejalan dengan penanaman karakter yang diharapkan oleh guru terhadap siswa yaitu karakter yang lain yang ada di dalam PPK religious, mandiri, gotong royong dan integritas

2. Peran Guru sebagai Pengelola Pembelajaran (Manager of Instruction) 
Dari hasil temuan yang dilakukan peneliti melalui studi wawancara online dan studi angket, bahwa peranan guru sebagai pengelola pembelajaran memiliki peran dalam menanamkan nilai karakter pada diri siswa dengan kondisi suasana kelas online yang kondusif, nyaman dan menyenangkan. Bagaimana guru pada waktu pembelajaran menggunakan zoom, google meet, atau membuat video pembelajaran mampu menggunakan pengetahuannya untuk memberikan apersepsi yaitu dengan membuka pelajaran dengan mengucapkan salam. Guru memutarkan lagu kebangsaan Indonesia Raya pada setiap pelajaran tentang sejarah, sehingga penanaman nilai karakter khususnya karakter nasionalisme pada diri siswa bisa berjalan dengan baik dan optimal. Dilanjutkan pada kegiatan inti guru mengucapkan Alhamdulillah jika peserta didik telah mengumpulkan tugas online tepat waktu. Pada kegiatan penutup, guru mengucapkan Insya Allah dalam setiap akhir pembelajaran untuk mengingatkan kembali pada pelajaran yang akan datang, yang dalam hal ini merupakan pengalaman tingkah laku pada siswa dan situasi belajar yang baik, dari hal tersebut diharapkan karakter yang muncul adalah karakter religius.

3. Peranan Guru sebagai Pengarah Pembelajaran Terhadap Pendidikan

Dari hasil temuan yang telah dilakukan peneliti dengan studi wawancara dan observasi, bahwa peranan guru sebagai pengarah pembelajaran dalam setiap pelaksanaan kegiatan pembelajaran guru selalu berusaha menimbulkan, memelihara dan meningkatkan motivasi belajar siswa. Dari setiap guru yang mengajar di google class room atau melalui zoom ataupun di chats whatsapp selalu memberi kata-kata penyemangat yang memotivasi siswa supaya tetap giat belajar walaupun pada situasi pandemic. Sehingga siswa dalam kegiatan belajar mengajar selalu bersemangat untuk belajar, dengan hal ini guru mengharapkan membentuk kebiasaan belajar yang baik serta menanamkan karakter mandiri bagi siswa dalam melaksanakan setiap kegiatan belajar mengajar di kelas. Dengan karakter yang diharapkan yaitu gorong royong, guru membuat pengalaman tingkah laku pada siswa dengan membentuk kelompok untuk membuat sebuah karya dari barang-barang yang sudah tidak terpakai. Dari kegiatan kelompok tersebut karakter yang muncul adalah karakter disiplin dan tanggungjawab, dan mandiri dimana siswa melakukan tugasnya dengan baik dan sesuai dengan petunjuk pengerjaan dan tanggung jawab terhadap tugas yang telah siswa bagi sendiri dalam kelompoknya. Timbul karakter kreatif karena tugas yang dikerjakan sesuai dengan pengembangan potensi yang ada dalam diri siswa tanpa harus bergantung kepada guru, siswa mengeksplorasi imajinasinya dalam melukis sehingga nanti hasil dari lukisan yang siswa buat dapat dipajang di kelas dengan rapih dan bagus. Namun pada kenyataannya berdasarkan data yang yang diperoleh hanya $20 \%$ siswa yang mengikuti pembelajaran berbasis video seperti zoom dan aplikasi right choice dan hanya $50 \%$ siswa yang mengumpulkan tugas. Itu membuktikan terjadi penurunan nilainilai karakter dalam diri peserta didik di masa pandemi ini.

4. Peranan Guru sebagai Evaluator Terhadap Pendidikan Karakter

Dari hasil temuan yang telah dilakukan peneliti dengan studi wawancara dan studi observasi, bahwa peran guru sebagai evaluator harus dilakukan secara terus menerus melihat tingkat keberhasilan, efektifitas dan efisiensi dalam proses pembelajaran. Dari hasil evaluasi yang dilakukan akan menjadi tolak ukur dalam meningkatkan hasil belajar siswa dalam setiap proses pembelajaran yang dilakukan guru di kelas. Peranan guru dalam hal ini sangat mempengaruhi terhadap perkembangan kegiatan belajar mengajar pada setiap pertemuannya. Karena itu pada setiap pertemuannya selalu diadakan evaluasi untuk melihat sejauh mana siswa mampu memahami pelajaran yang telah di jelaskan oleh guru dan bagaimana siswa dapat mengerjakan soal evaluasi yang dibuat melalui Aplikasi Right Choice yang dibuat dengan meminimalkan untuk siswa berbuat curang, akan tetapi diharapkan bahwa para siswa dapat melaksanakan karakter disiplin dan tanggung jawab. Dari hasil yang didapatkan bahwa siswa-siswi di SMP Negeri 1 Sumbang 95\% telah mengerjakan Penilaian Harian dan Penilaian Semester. Dari hasil ini bisa dikatakan bahwa siswa-siswi di SMP Negeri 1 Sumbang telah dapat menanamkan karakter integritas.

5. Peranan Guru sebagai Konselor terhadap Pendidikan Karakter Di Kelas

Dari hasil temuan yang telah dilakukan peneliti melalui studi wawancara dan studi observasi, bahwa peranan guru sebagai konselor adalah dimana guru melakukan layanan bimbingan kepada siswa, dengan peranannya sebagai konselor guru dapat menolong siswa dalam memecahkan masalah yang sedang dihadapinya, baik dari hasil prestasi belajar ataupun masalah yang terjadi antara siswa dengan temannya dan siswa dengan orang tuanya sendiri. Dalam hal ini secara bertahap guru pun menanamkan karakter disiplin, bertanggung jawab, jujur dan toleransi kepada diri siswa. Tentunya penanaman karakter tersebut disesuaikan dengan masalah yang sedang dialami siswa secara keseluruhan.

\section{KESIMPULAN}

Pendidikan karakter adalah sebuah gerakan yang dilakukan oleh setiap satuan pendidikan untuk membangun moral setiap siswa-siswinya. Pelaksanaan pendidikan karakter dilakukan lebih khususnya pada lingkungan kelas online, di sini guru memiliki peranan penting dalam menanamkan nilai-nilai karakter terhadap siswa sebagai bentuk perhatian guru untuk mengembangkan karakter siswa agar dalam setiap proses pembelajaran bisa berjalan dengan baik. Guru sebagai perancang pembelajaran memiliki peranan untuk merencanakan kegiatan belajar mengajar 
dengan materi yang relevan dan sistematis dengan demikian karakter yang diharapkan dari siswa yakni karakter nasionalisme terdapat dalam isi perencanaan yang dibuat oleh guru, dengan demikian perencanaan yang dibuat adalah bentuk peranan guru sebagai perancang pembelajaran. Guru sebagai pengelola pembelajaran memiliki peranan untuk membimbing setiap tingkah laku siswa serta kepribadiannya melalui pengelolaan kelas yang baik dengan demikian karakter yang muncul dari siswa adalah karakter mandiri, mandiri dalam mengerjakan tugasnya tanpa bergantung pada guru . Serta guru sebagai pengarah pembelajaran memiliki peranan untuk memberikan motivasi dan dorongan terhadap siswa untuk terus giat belajar sehingga karakter siswa yang mempunyai rasa integritas yang tinggi serta gotong royong sehingga dapat terbentuk secara bertahap sesuai dengan harapan guru. Dan guru sebagai evaluator dan konselor memiliki peranan untuk melihat hasil kerja siswa serta mengetahui masalah-masalah yang dialami oleh siswa, dengan evaluasi, guru mengikuti perkembangan siswa secara terus menerus dan jika masih ada hambatan yang terjadi pada siswa guru melakukan konselor sebagai tindak lanjut dari hambatan atau masalah yang sedang dialami siswa, sehingga guru dapat memperbaiki karakter pada diri individu siswa menjadi individu yang berkarakter disiplin, jujur, dan bertanggung jawab. Dengan demikian peranan guru dalam setiap proses pembelajaran sangat menentukan hasil dari pembentukan karakter yang dilakukan oleh guru terhadap siswanya di kelas.

\section{DAFTAR PUSTAKA}

[1] Undang-Undang Sisdiknas, Undang-undang No. 20 tahun 2003, (Pasal 1).Tentang Sistem Pendidikan Nasional. Jakarta

[2] Kesuma, Dharma, dkk. (2012). Pendidikan Karakter Kajian Teori dan Praktik di

Sekolah. Bandung: PT Remaja Rosda karya.

[3] Sugiyono. (2014). Metode Penelitian Kualitatif. Bandung: CV Alfabeta.

[4] Sugiyono. (2011). Metode Penelitian Kualitatif. Bandung: CV Alfabeta.

[5] Hamzah B, (2007). Profesi Kependidikan. Jakarta: Bumi Aksara

[6] KBBI, 2020. Kamus Besar Bahasa Indonesia,(KBBI). [Online

Available at: http://kbbi.web.id/peran [Diakses 20 Desember 2020].

[7] Depdikbud (1985). Tugas Guru Manajemen Kelas dan Metode Mengajar. Bandung. Kanwil Propinsi jawa Barat 